\title{
Health Issues and Mental Distress in French Active Farmers: A Quantitative and Qualitative Study
}

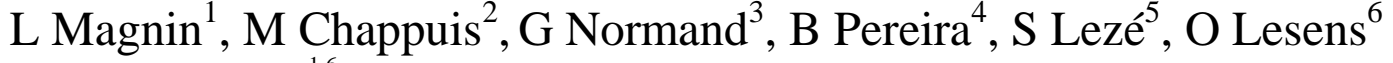 \\ ${ }^{1,6}$ Médecins du Monde, Auvergne-Rhône-Alpes, France \\ ${ }^{1,5}$ Institut d'Histoire des Représentations et des Idées dans les Modernités - UMR 5317, Ecole Normale Supérieure de Lyon, \\ Lyon, France \\ ${ }^{2}$ Médecins du Monde, Paris, France \\ ${ }^{4}$ Biostatistics Unit, Service de Délégation Recherche Clinique \& Innovation (DRCI), CHU Gabriel Montpied, Clermont- \\ Ferrand, France \\ ${ }^{6}$ Service des Maladies Infectieuses et Tropicales, CHU Clermont-Ferrand, France \\ ${ }^{6}$ Laboratoire Microorganismes: Génome Environnement (LMGE) UMR 6023, Université d'Auvergne, Clermont-Ferrand,
} France

Corresponding author: Pr Lesens Olivier; e-mail: olesens@chu-clermontferrand.fr Phone number: 04737549 35; Fax: 0473754934

\begin{abstract}
-
Purpose: Despite a particularly high suicide-related death rate observed in French farmers, data regarding this population's perception of health and their potential difficulties in accessing health care remains scarce.

Methods: We conducted a quantitative study involving 161 randomly selected farmers in three rural localities. Precarious conditions were assessed based on farmers' EPICES scores, their quality of life using the SF12 score, and their psychological distress by means of the GHQ-12. At the same time, a qualitative study was performed consisting in 16 indepth interviews.

Findings: In total, 112 farmers (70\% of persons contacted), most of them working as breeders for the meat-processing industry, participated in the study. Amongst them, 14.3\% had forgone doctor consultation within the last 12 months, and $19.6 \%$ had abstained from consulting a dentist. They expressed trust in their general practitioners but frequently resorted to alternative medicine or marginal practitioners when they considered their disease to be benign. The general physical health status measured using the SF12 was good in $84.5 \%$ of cases. However, $29.7 \%$ of respondents experienced psychological distress that seemed to originate primarily from the conflicting rhythms of agricultural timescales (seasonal calendar; local weather conditions; social rhythms, including administrative work; community rhythms). Factor analysis of mixed data showed that single farmers exhibiting social deprivation, who had inherited their farm, tended to be affected by psychological distress.
\end{abstract}

Conclusion: The consideration of mental distress in this identified population proves to be challenging issues that may help prevent suicide in farmers.

Key words: work stress, suicide, anthropology, access to health care.

\section{INTRODUCTION}

The French rural population has undergone a major shift over the last decades. According to the World Bank, although 21\% of the French live in rural areas, the active farmer population has decreased from 8\% in 1980 to $3.4 \%$ in 2007(1,2). Since the Second World War, agriculture has progressively shifted toward industrial processing, and the role of farmers increasingly resembles that of a manager, faced with an array of administrative tasks(3-5). Poverty has surged upward from 13\% in 2006 to $24 \%$ in 2010 in this population(2).

Farmers' health is still a subject of contention in France. In a prospective cohort involving 180,060 active and retired farmers from different areas in France, Levêque-Morlais $\mathrm{N}$ et al. showed that overall mortality and cancer-related death rates were significantly lower than those observed in the general population during the study period (2005-9)(6). The authors concluded that farmers allegedly were in better overall health than the general population. However, in a monitoring survey, the Institut de Veille Sanitaire (InVS), Saint-Maurice, France, demonstrated elevated suicide-related death rates, especially in male livestock farmers (56\% higher suicide rate for dairy farmers and $127 \%$ higher rate for livestock farmers working for the meat-processing industry in 2008)(7). Suicide and stress in farmers have been well documented in the UK(8-17) and Australia(18-22). However, the mechanisms underlying suicide are still poorly understood, especially in France(23-28). 
Given the scarcity of general practitioners in rural areas and the distance from rural residents' homes to secondary or tertiary health care facilities, access to health care may be hindered for persons living in rural areas. Since 2013, Médecins du Monde, (Doctors of the World), a well-known non-governmental organization, has been involved in a rural-area-based program (Combrailles, Auvergne, France) aiming to facilitate and coordinate access to health care and social rights. We observed nevertheless that only few farmers resorted to this program.

We conducted a qualitative and quantitative study designed to better understand this population's perception of their health, as well as potential difficulties experienced by farmers in accessing health care.

\section{METHODS}

\subsection{Quantitative study}

Information about the study was disseminated through articles in three local newspapers and by mail. Overall 200 farmers were randomly selected from an exhaustive database of active farmers residing in three localities (Pionsat, Menat and Cœur de Combrailles) in the territory of Combrailles (Puy de Dome, France). Amongst them, 39 were excluded due to incorrect addresses, retirement, or death. The remaining 161 randomly selected farmers received a mailing and subsequent phone call, whereby 15 could not be reached. The survey was performed from the $16^{\text {th }}$ of February to the $29^{\text {th }}$ of April 2015. Face-toface, 45-minute interviews took place at the farmers' places of residence after obtaining their written consent. The farmers were asked to fill out a questionnaire regarding their physical and mental health and their access to health care. Precarious conditions were assessed based on their EPICES score(29), and their quality of life using the SF12 score, which includes a physical score (Physical Composite Scores, PCS12) and mental health score (Mental Health Composite Scores, MCS12)(30). A value of $\leq 40$ was considered a sign of impaired physical or mental quality of life. Psychological distress was assessed using the General Health Questionnaire (GHQ-12), consisting of four subscales: somatic symptoms, anxiety and insomnia, social dysfunction, and severe depression. A GHQ-12 score of $\geq 2$ was considered positive for psychological distress.

\subsection{Statistics}

Descriptive analyses of the study population were performed using the software program Stata (Version 12). Continuous variables were expressed as mean and standard deviation (SD), whilst categorical variables were expressed as numbers and percentages. To better describe the population type affected by psychological distress, we performed an exploratory factor analysis as a factor analysis of mixed data (FAMD) expressed in data tables in which a group of individuals is described by both quantitative and qualitative variables(31). These methods are particularly useful in identifying the underlying relationships between measured variables and determining a set of latent constructs underlying measured variables, as well as aggregating subjects into clusters such that each cluster represents a topic. The parameters selected for inclusion in the process were chosen according to univariate results and clinical relevance. The term mixed refers to the simultaneous presence, as active elements, of both quantitative and qualitative variables.

\subsection{Qualitative study}

In-depth interviews $(\mathrm{N}=16)$ were performed in order to collect data about the farmers. These interviews were all conducted in the participant's own home, lasting 90 minutes on average (30 minutes to three hours). The interviewer asked open-ended questions in the hope of inciting participants to share developments in their health behavior. The qualitative interviews further explored: 1) the issues arising from the quantitative phase; 2) the heuristic scope by lending greater significance to the participant's point of view; 3) the participants' understanding of the agricultural activity sector. The core aspects of the interview focused on the concept of therapeutic itinerary. This notion englobes all responses that constitute the strategy, or quest, to be cured, whether such measures are pursued within or outside of the official health care system(32,33). Audiotapes of interviews were analyzed to select the most significant parts that were transcribed, compared and coded according to the turning points of the therapeutic itinerary.

\section{RESULTS}

\subsection{Demographic characteristics}

Of the 161 subjects contacted, 15 (9.3\%) could not be reached, and 34 (21.1\%) refused to participate (lack of time: 17; lack of interest: 10; other or no reason: 7). Altogether, 112 farmers (70\% of persons contacted) participated in the study. Of them, two were unable to respond to the SF12 and one could not respond to the GHQ-12. The vast majority of farmers were native to the area, lived with a partner, had inherited their farm, worked for the meat-processing industry, and produced the feed for their livestock (Table 1). Most of them had a full-time job with only a few days of leave each year. 
TABLE 1

SOCIODEMOGRAPHIC CHARACTERISTICS OF FARMERS $(\mathrm{n}=112)$

\begin{tabular}{|c|c|}
\hline Sociodemographic characteristics & Total \\
\hline Gender, male, $\mathrm{n}(\%)$ & $84(75.0 \%)$ \\
\hline Mean age (years) \pm SD (ranges) & $48.6 \pm 10.9(26-74)$ \\
\hline Native to area, $\mathrm{n}(\%)$ & $97(86.6 \%)$ \\
\hline Homeowner & $93(83.0 \%)$ \\
\hline $\begin{array}{l}\text { Live alone } \\
\text { Social relationships } \\
-\quad \text { Feel isolated or somewhat isolated } \\
-\quad \text { Meet other family members less than once a month } \\
-\quad \text { Meet friends or neighbors less than once a month }\end{array}$ & $\begin{array}{l}16(14.3 \%) \\
30(26.8 \%) \\
12(10.7 \%) \\
2(1.8 \%)\end{array}$ \\
\hline $\begin{aligned} \text { Family } & \text { situation } \\
- & \text { Single } \\
- & \text { Household members, mean } \pm \text { SD } \\
- & \text { Children }\end{aligned}$ & $\begin{array}{l}28(25.0 \%) \\
2.6 \pm 1.1 \\
38(33.9 \%)\end{array}$ \\
\hline $\begin{aligned} \text { Education } & \\
- & \text { Primary - secondary school } \\
- & \text { University }\end{aligned}$ & $\begin{array}{l}98(87.5 \%) \\
14(12.5 \%)\end{array}$ \\
\hline $\begin{array}{cl}\text { Monthly household income } \\
-\quad<1,200 \text { euros, } \mathrm{n}(\%) \\
-\quad 1,200-2,000 \text { euros, } \mathrm{n}(\%) \\
-\quad>2,000 \text { euros, } \mathrm{n}(\%) \\
-\quad & \text { No response, } \mathrm{n}(\%)\end{array}$ & $\begin{array}{l}40(35.7 \%) \\
39(34.8 \%) \\
26(23.2 \%) \\
7(6.3 \%)\end{array}$ \\
\hline $\begin{array}{l}\text { Social deprivation }^{1} \\
\quad \text { Precarious: } 30.17 \leq \text { EPICES scores }<53.84 \\
-\quad \text { Very precarious: EPICES scores } \geq 53.8 \\
\text { Feel financially insecure }\end{array}$ & $\begin{array}{l}31(27.7 \%) \\
3(2.7 \%) \\
52(46.4 \%)\end{array}$ \\
\hline $\begin{aligned} \text { Farm characteristics } \\
\text { Farm history } \\
\text { - } \quad \text { Inherited farm } \\
-\quad \text { Created farm } \\
\text { - } \quad \text { Other } \\
\text { Farm activity } \\
-\quad \text { Breeding } \\
-\quad \text { Livestock for meat production } \\
-\quad \text { Dairy livestock } \\
-\quad \text { Dairy and meat } \\
-\quad \text { Other } \\
\text { - } \quad \text { Produce feed for their livestock } \\
\text { Farmer's activity } \\
-\quad \text { Working days/week (high season), mean } \pm S D \\
-\quad \text { Working days/week (low season), mean } \pm S D \\
-\quad \text { No leave in the last } 12 \text { months } \\
-\quad \text { Mean leave time per year } \pm S D \text { (in days) }\end{aligned}$ & $\begin{array}{l}84(75.0 \%) \\
25(22.3 \%) \\
3(2.7 \%) \\
109(97.0 \%) \\
93(83.0 \%) \\
6(5.4 \%) \\
8(7.1 \%) \\
2(1.8 \%) \\
99(88.4 \%) \\
6.9( \pm 0.3) \\
6.6( \pm 0.7) \\
63(56.3 \%) \\
4.5( \pm 0.4)\end{array}$ \\
\hline $\begin{aligned} & \text { Reasons for not taking leave }(\mathbf{n}=\mathbf{6 3}) \\
&-\quad \text { Overworked/no time } \\
&-\quad \text { Indispensable role on the farm } \\
&-\quad \text { No desire/do not like vacation } \\
&-\quad \text { Cannot afford it } \\
&- \text { Other }\end{aligned}$ & $\begin{array}{l}18(28.6 \%) \\
17(27 \%) \\
16(25.4 \%) \\
11(17.5 \%) \\
1(1.6 \%)\end{array}$ \\
\hline
\end{tabular}

${ }^{I}$ EPICES scores $\geq 30.17$ defined the deprived population (EPICES score were able to be calculated for 110 farmers) 


\subsection{Physical health}

Whilst interviewed, farmers stated they felt healthy, enjoying good disease resistance, a healthy lifestyle and good dental health; yet there were frequent reports of chronic diseases, obesity, active smoking, and unreplaced teeth (Table 2).

TABLE 2

PHYSICAL AND MENTAL HEALTH OF FARMERS

\begin{tabular}{|c|c|}
\hline $\begin{array}{l}\text { Physical health } \\
\text { Impaired nhysical aulity of life }(\mathrm{P} C \mathrm{~S} 12<40)(\mathbf{N}-\mathbf{1 1 0})\end{array}$ & Total \\
\hline Impaired physical quality of life $(\mathrm{PCS} 12 \leq 40)(\mathbf{N}=\mathbf{1 1 0})$ & $17(15.5 \%)$ \\
\hline Feel they have good disease resistance & $95(84.8 \%)$ \\
\hline Feel they have a healthy lifestyle & $94(83.9 \%)$ \\
\hline Chronic diseases (one or several) & $45(40.2 \%)$ \\
\hline - Diabetes & $5(4.5 \%)$ \\
\hline - Cancer & $3(2.7 \%)$ \\
\hline - Cardiovascular disease & $12(10.7 \%)$ \\
\hline - $\quad$ Pulmonary disease & $8(7.1 \%)$ \\
\hline - Neurological disease & $8(7.1 \%)$ \\
\hline - Depressive syndrome & $4(3.6 \%)$ \\
\hline - Osteoarticular syndrome & $11(9.8 \%)$ \\
\hline - Other & $16(14.3 \%)$ \\
\hline \multicolumn{2}{|l|}{ BMI } \\
\hline - Overweight $(25 \leq \mathrm{BMI}<30)$ & $39(34.8 \%)$ \\
\hline - Obesity $(\mathrm{BMI} \geq 30)$ & $20(17.9 \%)$ \\
\hline \multicolumn{2}{|l|}{ Oral-dental condition } \\
\hline - Relatively good to very good & $98(87.5 \%)$ \\
\hline \multicolumn{2}{|l|}{ Number of missing, unreplaced teeth } \\
\hline - None/Zero & $62(55.4 \%)$ \\
\hline - $\quad$ At least 1 & $49(43.8 \%)$ \\
\hline - 1 to 4 teeth & $36(32.1 \%)$ \\
\hline - 5 to 9 teeth & $11(9.8 \%)$ \\
\hline - $\quad \geq 10$ teeth & $2(1.8 \%)$ \\
\hline - Do not know & $1(0.9 \%)$ \\
\hline Mental health & Total \\
\hline \multirow{6}{*}{$\begin{array}{l}\text { Impaired mental quality of life (MCS12 } \leq 40)(\mathbf{n}=\mathbf{1 1 0}) \\
\text { Psychological distress (GHQ12 } \geq 2)(\mathbf{n}=\mathbf{1 1 1}) \\
\text { Administration of psychotropic substances (in the last } 12 \text { months) } \\
\text { Find their work physically tiring } \\
\text { Find their work mentally tiring } \\
\text { Insomnia due to work }\end{array}$} & $32(29.0 \%)$ \\
\hline & $33(29.7 \%)$ \\
\hline & $15(13.4 \%)$ \\
\hline & $95(84.8 \%)$ \\
\hline & $84(75.0 \%)$ \\
\hline & $58(51.8 \%)$ \\
\hline \multicolumn{2}{|l|}{ Addictions } \\
\hline Smoking & $29(25.9 \%)$ \\
\hline $\begin{array}{l}\text { Number of cigarettes per day, mean } \pm \text { SD } \\
\text { Increased tobacco use due to work over the last } 12 \text { months (For daily smokers, } \mathbf{n = 2 0} \text { ) }\end{array}$ & $14.5 \pm 8.2$ \\
\hline \multirow{2}{*}{$\begin{array}{l}\text { Increased tobacco use due to work over the last } 12 \text { months (For daily smokers, } \mathbf{n = 2 0} \text { ) } \\
\text { Alcohol consumption }\end{array}$} & \\
\hline & $6(30.0 \%)$ \\
\hline - Never & \\
\hline - Once a month or less & $17(15.2 \%)$ \\
\hline - $\quad 2$ to 4 times a month & $16(14.3 \%)$ \\
\hline - $\quad 2$ to 3 times a week & $35(31.3 \%)$ \\
\hline - 4 to 6 times a week & $17(15.2 \%)$ \\
\hline - Every day & $3(2.7 \%)$ \\
\hline Number of drinks per day, mean \pm SD & $24(21.4 \%)$ \\
\hline Increased alcohol consumption due to work over the last 12 months (For drinkers, & $2.3 \pm 1.5$ \\
\hline $\mathrm{n}=\mathbf{9 5})$ & $2(2.1 \%)$ \\
\hline
\end{tabular}

\subsection{Mental health}

Farmers frequently exhibited impaired mental quality of life (SF12) and psychological distress (GHQ-12) (Table 2). In univariate analysis, mental distress was associated with a full time activity and few leave, feeling of solitude and difficulties in work (table 4). FAMD analysis results demonstrated a dichotomy between two main groups (Figure 1): 1) single farmers 
affected by social deprivation who had inherited their farms tended to display psychological distress; 2) in contrast, farmers with a higher educational level, who had created their own farms and took more time off, appeared to be less prone to stress.
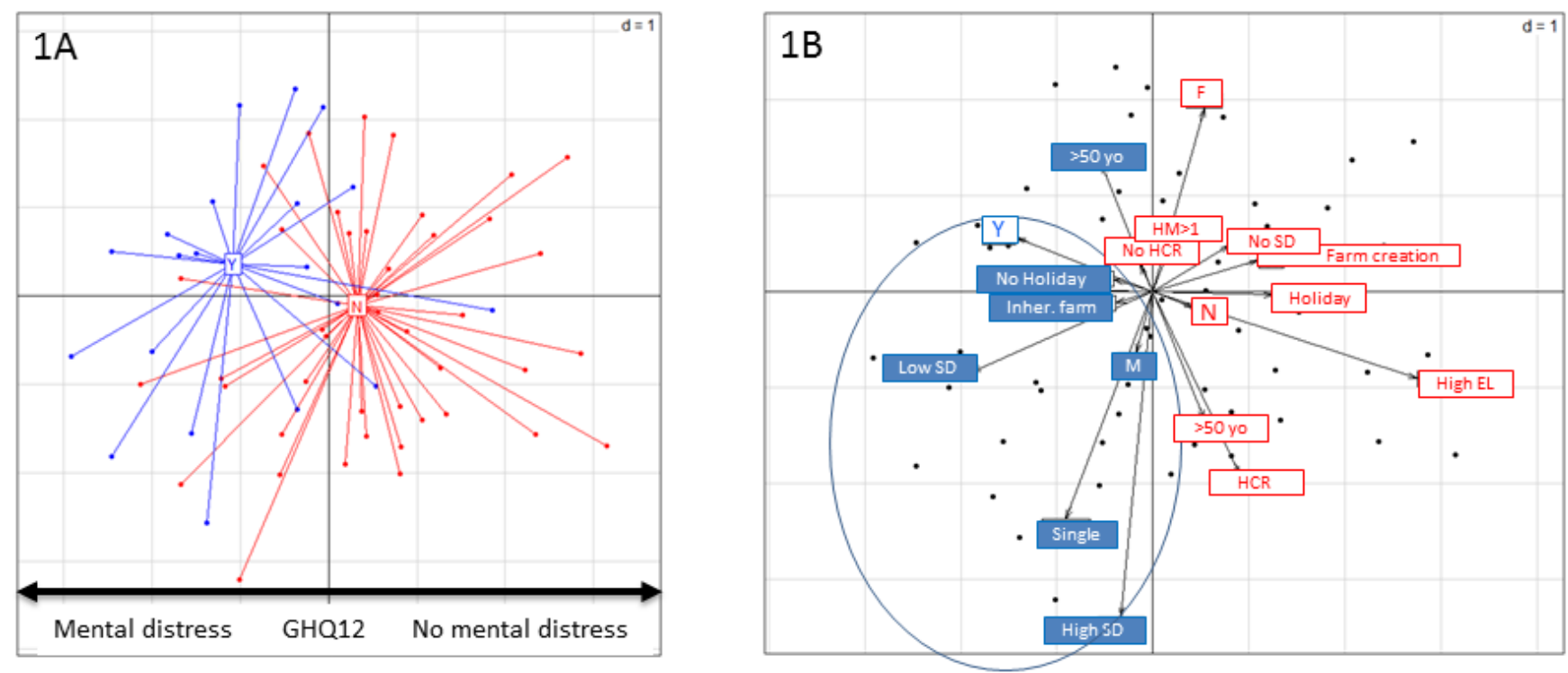

FIGURE 1: RESULTS OF FAMD. 1A. FARMERS REPRESENTATION ACCORDING TO GHQ12 SHOWING 2 CLUSTERS, ONE WITH MENTAL DISTRESS (Y, BLUE), ANOTHER WITH NO MENTAL DISTRESS (N, RED). 1B: VARIABLES REPRESENTATION SHOWING ONE CLUSTER (IN BLUE) EXPOSED TO MENTAL STRESS (Y) THAT MAINLY INCLUDES SINGLE FARMERS WITH SOCIAL DEPRIVATION AND INHERITED FARMS. SD: Social Deprivation; M: Male; F: Female; Inher. Farm: Inherited Farm; yo: Year old; HCR: Health Care Renouncement; EL: Educational Level; HM: Household Members

The qualitative study's results highlighted that for active farmers, mental disorders, and especially depression, were perceived as diseases that should be discussed with and treated by a doctor. As for other diseases, many preferred to resort to a doctor only if they viewed them to be severe. Some farmers felt that mental disorders differed from other diseases and should be overcome by means of their own willpower, without any doctor's assistance.

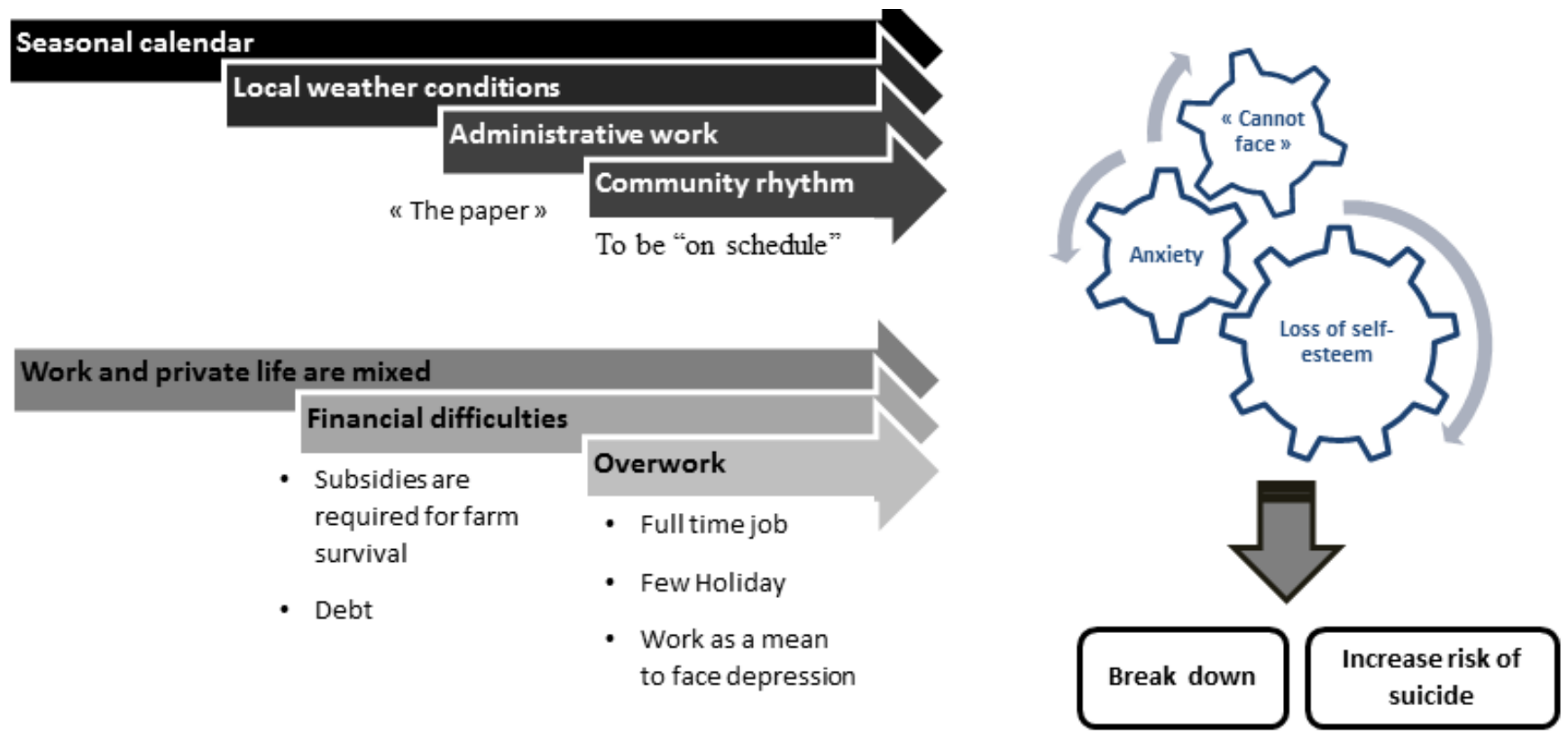

FIGURE 2: SCHEMATIC REPRESENTATION OF THE MULTIPLE FACTORS IDENTIFIED IN THE QUALITATIVE STUDY THAT MAY LEAD TO MENTAL DISTRESS AND MAY EXPLAIN FOR A PART THE INCREASE RISK OF SUICIDE IN THE POPULATION

Anxiety was a common symptom in active farmers and seemed to mainly originate from the conflicting rhythms of agricultural timeframes, specific to this population (Figure 2). Indeed, agricultural timeframes are subject to different 
rhythms, including the seasonal calendar ("In winter, it's time for calving, and then it's time to tend to the corn, then hay, harvesting, ploughing, silage, and then it's time to sow... We end up never having any time left, you know."), local weather conditions (which may affect the work schedule) and social rhythms. In terms of social rhythms, farmers consistently broached the topic of administrative work ("paperwork"): "We have two bosses-the weather and 'them' [the Common Agricultural Policy, CAP]". As a prerequisite in order to obtain CAP-based subsidies (which are crucial for farmers' subsistence), this administrative work constituted the greatest source of anxiety for farmers, who described the CAP's rules for receiving subsidies as opaque and unpredictable: "[...] it stresses you out, because you never know how to properly fill out your paperwork in order to meet expectations". Another anxiety-provoking social rhythm was dictated by the community, whereby the progress of farmers' work was compared to that of their local farming community. For farmers, being "on schedule" meant having made similar headway in their farming tasks as their counterparts within a closed community. "Getting behind" bore a tacit social stigma - such farmers tended to be excluded from the community (loss of credibility, teasing) or to withdraw from various social activities (farmers' meetings, community celebrations, or festivities). Furthermore, ensuing psychological consequences included loss of self-esteem and anxiety. Given the inherent overlap between private and professional life in the agricultural sector ("Our life is our work-it's all interwoven."), one's professional status was perceived to reflect individuals' intrinsic value as human beings and was therefore highly associated with self-esteem.

Farmers generally felt the best remedy for depression was work ("And how do you keep your chin up?" "By working". "Work keeps you going strong?" "Yes. We have a lot of work [...]"). Their response to anxiety or depression tended not to be taking time off, and some considered that meeting people was the best way to reduce stress (for instance, woofing is a practice specific to farmers, allowing them to meet people from the "outside").

\subsection{Relationship with the health care system and abstention from health care}

Farmers usually had a general practitioner (GP) they trusted even if they felt that the information provided was at times difficult to understand, with recommendations difficult to adhere to (Table 3). Moreover, numerous farmers resorted to alternative medicine and turned to marginal practitioners. When ill, $44.6 \%$ preferred to wait before seeing a doctor, and $40.2 \%$ self-medicated as their first-line therapy ( $8.9 \%$ took alternative medications). Participants generally had private complementary health insurance.

According to the study's qualitative results, the health care system seemed to generally enjoy farmers' trust when it came to managing severe diseases. Organic farmers tended to criticize conventional medicine and resort to alternative medicine for minor health problems. They accused their GPs of being inattentive to their demands, thereby focusing on a single part of the body, rather than employing a holistic approach, and of systematically prescribing medications. However, they did not hesitate to consult a conventional doctor if they felt they were affected by a severe disease, just as they would resort to a veterinarian for their livestock instead of a home remedy or an alternative treatment if deemed necessary. Some farmers had acquired personal knowledge about health problems (that may be misguided, in the case of Lyme disease, for example) and chose to employ conventional or alternative medicine according to their personal conception of the disease and its severity.

Overall, $14.3 \%$ had abstained from consulting a doctor over the last 12 months and $19.6 \%$ a dentist (Table 3). This was accounted for in part by financial constraints and the fear of health care or health care workers cited in the qualitative study. Although the vast majority of farmers had a good complementary insurance plan, financial issues remained a crucial reason why farmers with limited resources abstained from accessing health care. First of all, in many cases, patients were required to pay the doctor in advance before subsequently being reimbursed by their insurance and this proved unaffordable for some ("I don't have 20 Euros to spend"). Secondly, farmers were at times deterred by transport costs necessary to be able reach a specialist ("I have to watch my spending when filling up on gas to go to hospital, because money is tight. It takes me an hour to drive there and so I sometimes choose to live with my pain, since even if the consultation itself were free, I couldn't afford the gas bill.”). Another reason farmers abstained from accessing health care was the fear of health care professionals (especially dentists), of the care itself (fear of diagnosis, pain, or treatment failure): "[...] I know they are health care professionals [...], they know their job, but I'm scared". Lastly, many active farmers claimed they forewent care due to time constraints. This response appeared to be the more socially acceptable for active farmers, but might have concealed more complex situations in which financial reasons, transportation issues, fear and negligence were often intertwined. Their alleged lack of time might have also served as a pretext in order to mask the higher priority attributed by active farmers attributed to their work than to their own health ("Livestock is treated better than humans - that goes without saying."). This 
frequent behavior was accounted for by how highly farming work was valued compared to the relatively marginalized role of farmers' personal lives.

\section{TABLE 3}

FARMERS' RELATIONSHIP WITH THE HEALTH CARE SYSTEM AND THEIR ABSTENTION TO CONSULT A HEALTH CARE PROFESSIONAL

\begin{tabular}{|c|c|}
\hline Variables & $\mathbf{N}(\%)$ \\
\hline Have a general practitioner (GP) & $104(92.9 \%)$ \\
\hline Trust their doctors (fully/very much) & $95(84.8 \%)$ \\
\hline Information from doctors is difficult to understand (absolutely/very much so) & $48(42.9 \%)$ \\
\hline $\begin{array}{l}\text { GP's recommendations are difficult to adhere to } \\
\text { (absolutely/very much so) }\end{array}$ & $84(75.0 \%)$ \\
\hline $\begin{array}{l}\text { Complementary health insurance } \\
\begin{array}{c}\text { - } \\
\text { - }\end{array} \text { CMUivate complementary insurance } \\
\text { - } \quad \text { No complementary insurance }\end{array}$ & $\begin{array}{l}104(92.9 \%) \\
6(5.4 \%) \\
2(1.8 \%)\end{array}$ \\
\hline $\begin{array}{l}\text { Health care access } \\
\text { At least one consultation over the past } 2 \text { years } \\
\begin{aligned} \text { - } & \text { GP } \\
\text { - } & \text { Ophthalmologist } \\
\text { - } & \text { Other specialist } \\
\text { - } & \text { Gynecologist (for women, } \mathrm{n}=28) \\
\text { - } & \text { Dentist } \\
\text { - } & \text { Alternative medicine (acupuncture, osteopath, etc.) } \\
\text { - } & \text { Marginal practitioner }\end{aligned}\end{array}$ & $\begin{array}{l}101(90.2 \%) \\
49(43.8 \%) \\
40(35.7 \%) \\
17(60.7 \%) \\
73(65.2 \%) \\
45(40.5 \%) \\
19(17.0 \%)\end{array}$ \\
\hline $\begin{array}{l}\text { Screening } \\
\text { - } \quad \text { Colorectal cancer } \leq 2 \text { years (persons between } 50-74 \text { years old, } \mathbf{n = 5 8} \text { ) } \\
\text { - } \quad \text { Cervical cancer } \leq 3 \text { years (only for women } 25-65 \text { years old, } \mathbf{n = 2 7} \text { ) } \\
\text { - }\end{array}$ & $\begin{array}{l}10(17.2 \%) \\
19(70.4 \%) \\
12(63.2 \%)\end{array}$ \\
\hline $\begin{array}{l}\text { Abstention to consult a health care professional (in the last } 12 \text { months) } \\
-\quad \text { Doctor } \\
-\quad \text { Dentist } \\
-\quad \text { Both doctor and dentist }\end{array}$ & $\begin{array}{l}16(14.3 \%) \\
22(19.6 \%) \\
4(3.6 \%)\end{array}$ \\
\hline $\begin{aligned} & \text { Reason for abstention to consult doctor/dentist }(\mathbf{n}=\mathbf{3 4}) \\
& \text { - } \text { Lack of time } \\
&- \text { Fear of doctor/dentist } \\
&- \text { Waiting period } \\
&- \text { Distance/no doctor nearby } \\
&- \text { Negligence or no desire } \\
&- \text { Financial constraints } \\
&- \text { Deliberate postponement } \\
&- \text { No trust in practitioner } \\
&- \text { Negative experience with health care system } \\
&- \text { Too complicated } \\
&- \text { Other }\end{aligned}$ & $\begin{array}{l}22(64.7 \%) \\
10(29.4 \%) \\
6(17.6 \%) \\
4(11.8 \%) \\
3(8.8 \%) \\
3(8.8 \%) \\
3(8.8 \%) \\
3(8.8 \%) \\
2(5.9 \%) \\
1(2.9 \%) \\
2(5.9 \%)\end{array}$ \\
\hline
\end{tabular}


TABLE 4

VARIABLES ASSOCIATED WITH MENTAL DISTRESS (GHQ12>=2)

\begin{tabular}{|c|c|c|c|}
\hline & GHQ12>=2 (n=33) & GHQ12<2 (n=78) & $\mathrm{p}$ \\
\hline $\begin{array}{cl}\text { Gender } & \\
- & \text { Male, } \mathrm{n}(\%) \\
- & \text { Female, } \mathrm{n}(\%)\end{array}$ & $\begin{array}{l}24(72.7 \%) \\
9(27.3 \%)\end{array}$ & $\begin{array}{l}59(75.6 \%) \\
19(24.4 \%)\end{array}$ & 0.747 \\
\hline $\begin{array}{c}\text { Mean age (years) } \pm \text { SD } \\
-\quad 95 \% \text { CI } \\
\end{array}$ & $\begin{array}{l}51.2 \pm 10.5 \\
{[47.5-54.9]}\end{array}$ & $\begin{array}{l}47.4 \pm 11.1 \\
{[44.9-49.9]}\end{array}$ & 0.1523 \\
\hline $\begin{array}{c}\text { Native from the area } \\
-\quad \text { Yes } \\
-\quad \text { No } \\
\end{array}$ & $\begin{array}{l}28(84.9 \%) \\
5(15.2 \%)\end{array}$ & $\begin{array}{l}68(87.2 \%) \\
10(12.8 \%)\end{array}$ & 0.743 \\
\hline Home owner & $28(84.9 \%)$ & $64(82.1 \%)$ & 0.721 \\
\hline Lives alone in their housing ( $\&$ without children) & $5(15.2 \%)$ & $11(14.1 \%)$ & 0.886 \\
\hline $\begin{aligned} & \text { Family situation } \\
&- \text { Single } \\
&- \text { Presence of children } \\
&\end{aligned}$ & $\begin{array}{l}10(30.3 \%) \\
8(24.2 \%)\end{array}$ & $\begin{array}{l}18(23.1 \%) \\
30(38.5 \%)\end{array}$ & $\begin{array}{l}0.423 \\
0.149\end{array}$ \\
\hline $\begin{array}{c}\text { Educational level* } \\
-\quad \text { Primary- Secondary school } \\
-\quad \text { University } \\
\end{array}$ & $\begin{array}{l}30(90.9 \%) \\
3(9.1 \%)\end{array}$ & $\begin{array}{l}67(85.9 \%) \\
11(14.1 \%)\end{array}$ & 0.549 \\
\hline $\begin{array}{cl}\text { Finance ressources } \\
\text { Income } & \\
- & <1000 \text { euros, } \mathrm{n}(\%) \\
- & 1000-2000 \text { euros, } \mathrm{n}(\%) \\
- & >2000 \text { euros, } \mathrm{n}(\%) \\
- & \text { Feel financially unsecure } \\
- & \text { Difficulties to face needs } \\
\end{array}$ & $\begin{array}{l}9(29.0 \%) \\
16(51.6 \%) \\
6(19.4 \%) \\
16(48.5 \%) \\
13(40.6 \%) \\
\end{array}$ & $\begin{array}{l}10(13.7 \%) \\
44(60.3 \%) \\
19(26.0 \%) \\
36(46.2 \%) \\
22(28.2 \%)\end{array}$ & $\begin{array}{l}0.175 \\
0.822 \\
0.204 \\
\end{array}$ \\
\hline $\begin{array}{c}\text { EPICES score }(\mathbf{n}=\mathbf{1 1 0 , 1 0 8}) \\
<30.17 \text { (no precarious) } \\
>=30.17 \text { (precarious) }\end{array}$ & $\begin{array}{l}19(59.4 \%) \\
13(40.6 \%)\end{array}$ & $\begin{array}{l}56(72.7 \%) \\
21(27.3 \%)\end{array}$ & 0.171 \\
\hline Work every days $(7 / 7)$ & $27(81.8 \%)$ & $47(61.0 \%)$ & 0.033 \\
\hline Holidays (mean number of days) & $\begin{array}{l}1.6( \pm 2.8) \\
{[0.7-2.6]}\end{array}$ & $\begin{array}{l}3.9( \pm 5.3) \\
{[2.7-5.1]}\end{array}$ & 0.0425 \\
\hline Use Replacement service & $11(33.3 \%)$ & $25(32.1 \%)$ & 0.895 \\
\hline Health - Have a GP & $28(84.9 \%)$ & $75(96.2 \%)$ & 0.049 \\
\hline $\begin{array}{l}\text { Chronic disease } \\
\text { Depressive syndrome }\end{array}$ & $\begin{array}{l}16(48.5 \%) \\
3(9.1 \%)\end{array}$ & $\begin{array}{l}28(35.9 \%) \\
1(1.3 \%)\end{array}$ & $\begin{array}{l}0.215 \\
0.078\end{array}$ \\
\hline $\begin{array}{l}\text { Health feeling } \\
\quad-\quad \text { Excellent/Very good/ Good } \\
-\quad \text { Bad/Mediocre }\end{array}$ & $\begin{array}{l}22(66.7 \%) \\
11(33.3 \%)\end{array}$ & $\begin{array}{l}73(93.6 \%) \\
5(6.4 \%)\end{array}$ & 0.000 \\
\hline Health care renouncement (q53) (doctor) & $10(30.3 \%)$ & $6(7.7 \%)$ & 0.002 \\
\hline Smoking & $9(27.3 \%)$ & $19(24.4 \%)$ & 0.747 \\
\hline $\begin{array}{cl}\text { Alcohol } & \\
- & \text { Non-drinker (Never/Once a month or less) } \\
- & \text { Occasional (2 to } 4 \text { times a month) } \\
\text { - } & \text { Reasonable (2 to } 6 \text { times a week, every day } \&<3 \\
& \text { glasses/day) } \\
\text { - } & \text { Excessive (every day \& }>=3 \text { glasses/day) } \\
\end{array}$ & $\begin{array}{l}16(48.5 \%) \\
5(15.2 \%) \\
9(27.3 \%) \\
3(9.1 \%)\end{array}$ & $\begin{array}{l}17(21.8 \%) \\
30(38.5 \%) \\
27(34.6 \%) \\
4(5.1 \%)\end{array}$ & 0.012 \\
\hline Psychotropic consumption & $6(18.2 \%)$ & $9(11.5 \%)$ & 0.349 \\
\hline $\begin{array}{l}\text { Social relations } \\
\quad \quad \quad \text { Feel isolated or rather isolated }\end{array}$ & $19(57.6 \%)$ & $10(12.8 \%)$ & 0.000 \\
\hline $\begin{array}{cl}\text { Work feeling } \\
- & \text { Find their work nervously tiring } \\
- & \text { Find their work physically tiring } \\
- & \text { Insomnia due to work } \\
\end{array}$ & $\begin{array}{l}30(90.9 \%) \\
32(97.0 \%) \\
30(90.9 \%)\end{array}$ & $\begin{array}{l}53(68.0 \%) \\
62(79.5 \%) \\
53(68.0 \%)\end{array}$ & $\begin{array}{l}0.015 \\
0.020 \\
0.015\end{array}$ \\
\hline \begin{tabular}{ll}
\multicolumn{2}{l}{ Characteristics of exploitation } \\
History & \\
- & Familial exploitation \\
Size & \\
- & Mean area cultivated (hectares) \\
Status & \\
- & Individually exploitation \\
- & Other (GAEC, EARL)
\end{tabular} & $\begin{array}{l}24(72.7 \%) \\
25.3 \pm 27.1 \\
{[15.1-35.4]} \\
19(57.6 \%) \\
14(42.4 \%)\end{array}$ & $\begin{array}{l}59(75.6 \%) \\
29.6 \pm 33.9 \\
{[21.4-37.7]} \\
32(41.0 \%) \\
46(59.0 \%)\end{array}$ & $\begin{array}{l}0.747 \\
0.4177 \\
0.110\end{array}$ \\
\hline
\end{tabular}




\section{DISCUSSION}

Data remains scarce regarding the health of French farmers. We thus studied a representative sample of farmers, most of which working for the meat-processing industry. This category of farmers is known to exhibit an elevated suicide rate. Whereas most farmers claimed to have few health problems, we found that $29.7 \%$ of farmers interviewed were affected by psychological distress. This population was mainly composed of single farmers subject to social deprivation and who had inherited their farms. This qualitative study casts light on the causes of this mental affliction, which have been summarized in Figure 1. Furthermore, better understanding of such suicide cases may contribute to their prevention.

As in previous studies, we observed participants' general physical health to be good in $84.5 \%$ of cases, with their physical quality of life measured based on a Physical composite score of SF12 (PCS>40). That said, whilst farmers tended to view their way of life as healthy and felt they enjoy good disease resistance, their personal conception of their own health may diverge from reality given that many are being treated for a chronic disease, whilst smoking and obesity were observed more frequently in farmers $<50$ years of age than in the general population(34,35). Moreover, a lower percentage of farmers underwent screening for cancer than of the general population. Finally, subjects' oral-dental health was determined to be mediocre, based on the number of missing and unreplaced teeth. Farmers' relationship with the health care system may differ from that of urban residents. Even if they were shown to trust their doctors and get good health insurance, it also became clear that they tend to diagnose themselves based on personal knowledge when they consider a disease to be benign or when the feel the GP is unable to make the proper diagnosis, or prescribe the right treatment. Overall $14.3 \%$ of farmers admitted they had foregone consulting their GP and dentist for reasons that are typically described in rural areas (mainly lack of time, fear, excessive waiting periods, distance to medical facilities, and financial constraints), but also because they often prioritize their work over their own health. Abstention to access health care occurred more frequently in the event of dental care $(19.6 \%)$.

In contrast with physical health, $29.7 \%$ of farmers admitted to experiencing psychological distress, which may result from several interrelated factors. Firstly, farmers must generally adhere to a schedule: They are required to adapt their work to the seasons and local weather conditions, as has historically been the case, but modern French farmers face the additional hurdle of administrative work in order to obtain subsidies from the European Union that are crucial for their subsistence. "Paperwork" must be completed according to strict deadlines, thereby hindering farmers in performing their job. Such bureaucratic tasks do not fall within the traditional scope of farmers' duties (information required is often described as inappropriate and perceived as a waste of time), and they equally symbolize farmers' failure to earn their living without relying upon subsidies. Finally, a sort of unspoken rule in gauging the quality of farmers' work consists in their ability to successfully match the progress of other local farmers. Each individual farmer perceives an obligation to keep in step with other farmers' progress and is thereby subjected to judgement by their farming community. Keeping "on schedule" constitutes a crucial sociological marker, and farmers who are "behind with their work" may be socially blacklisted by the farming community and, at the same time, tend to isolate themselves from the others. All these factors pertaining to time management exert continual pressure on farmers, which contributes to mental distress. A further detrimental effect upon farmers' mental health is their negative perception of their profession, combined with the overwhelming importance of work and marginalized role of private life. Financial difficulties, increased administrative work, as well as reliance upon subsidies have diminished the pride farmers once took in their job. This is exacerbated by the burnout experienced by many farmers, who practice a full-time profession that appears ineffective at overcoming its associated financial and administrative difficulties. Given that private and professional life is inextricably interwoven, the deterioration of the profession's image is damaging to farmers' personal self-image, coinciding with a loss of self-assurance and self-esteem. Associated with anxiety, this condition may contribute to depression, which may explain, at least to some extent, the increased suicide rate observed in this population.

Suicide prevention in farmers remains a challenge. In France, livestock farmers, who have an increased mortality rate due to suicide, may constitute a target population(7). However, efforts must still be made to identify farmers at risk of suicide in the context of the extensive technical, economical, and anthropological shifts that have affected the whole agricultural world since the Second World War(36,37). The second challenge is to implement a network designed to assist farmers at risk of suicide in a socially acceptable way for farmers. This network may consist of a group of trained farmers, able to detect and get in touch with farmers at risk(38). In addition, psychological distress (and not only depression) should be taken more into account(25), which implies expanding rural health services(39). Availability of GPs in rural areas is crucial in order to decrease the delay between requests and consultations and to increase the duration of consultations, thus facilitating physician-patient dialog about mental health(40). While some patients may require the assistance of a psychologist, it must 
also be mentioned that at present psychologists are scarce in rural areas, and their costs are not reimbursed by French social security. Other potential measures would consist of alleviating mental distress by promoting a new approach to work time management with more leisure time, expanding services to provide replacement workers, in addition to volunteer assistance exchanges such as the WWOOF (World Wide Opportunities on Organics Farms) system.

\section{Funding}

This study was funded by Médecins $d u$ Monde.

\section{Competing interests None.}

Ethics approval This study received approval from the French National Consultative Ethics Committee.

\section{REFERENCES}

[1] [cited 2016 Feb 21]. Available from: http://donnees.banquemondiale.org/indicateur/SP.RUR.TOTL.ZS

[2] Laisney C. Les agriculteurs dans la société française. Ministère L'Agriculture Cent D'études Prospect. 2010;(14).

[3] Deléage E. Agricultures à l'épreuve de la modernisation. Versailles Quae; 2013. 95 p. (Synthèses).

[4] Jacques-Jouvenot D, Laplante J-J. Les maux de la terre: Regards croisés sur la santé au travail en agriculture. La Tour d'Aigues: Editions de l'Aube; 2009. 215 p.

[5] Nicourt C. Être agriculteur aujourd'hui : l'individualisation du travail des agriculteurs. Versailles Quae; 2013.287 p. (Nature et société).

[6] Levêque-Morlais N, Tual S, Clin B, Adjemian A, Baldi I, Lebailly P. The AGRIculture and CANcer (AGRICAN) cohort study: enrollment and causes of death for the 2005-2009 period. Int Arch Occup Environ Health. 2015;88(1):61-73.

[7] Bossard C, Santin C, Guseva Canu I. Surveillance de la mortalité par suicide des agriculteurs exploitants [Internet]. 2013 [cited 2016 Jan 22]. Available from: http://www.invs.sante.fr/Publications-et-outils/Rapports-et-syntheses/Travail-et-sante/2013/Surveillance-dela-mortalite-par-suicide-des-agriculteurs-exploitants

[8] Malmberg A, Hawton K, Simkin S. A study of suicide in farmers in England and Wales. J Psychosom Res. 1997 Jul;43(1):107-11.

[9] Simkin S, Hawton K, Fagg J, Malmberg A. Stress in farmers: a survey of farmers in England and Wales. Occup Environ Med. 1998 Nov;55(11):729-34.

[10] Hawton K, Fagg J, Simkin S, Harriss L, Malmberg A. Methods used for suicide by farmers in England and Wales. The contribution of availability and its relevance to prevention. Br J Psychiatry J Ment Sci. 1998 Oct;173:320-4.

[11] Malmberg A, Simkin S, Hawton K. Suicide in farmers. Br J Psychiatry. 1999 Aug 1;175(2):103-5.

[12] Hawton K, Fagg J, Simkin S, Harriss L, Malmberg A, Smith D. The geographical distribution of suicides in farmers in England and Wales. Soc Psychiatry Psychiatr Epidemiol. 1999 Apr;34(3):122-7.

[13] Simkin S, Hawton K, Yip PSF, Yam CHK. Seasonality in suicide: a study of farming suicides in England and Wales. Crisis. 2003;24(3):93-7.

[14] Deary IJ, Willock J, Mcgregor M. Stress in Farming. Stress Med. 1997 avril;13(2):131-6.

[15] Booth N, Briscoe M, Powell R. Suicide in the farming community: methods used and contact with health services. Occup Environ Med. 2000 Sep;57(9):642-4.

[16] Booth NJ, Lloyd K. Stress in Farmers. Int J Soc Psychiatry. 2000 Mar 1;46(1):67-73.

[17] Hounsome B, Edwards RT, Hounsome N, Edwards-Jones G. Psychological Morbidity of Farmers and Non-farming Population: Results from a UK Survey. Community Ment Health J. 2011 May 10;48(4):503-10.

[18] Fraser CE, Smith KB, Judd F, Humphreys JS, Fragar LJ, Henderson A. Farming and Mental Health Problems and Mental Illness. Int J Soc Psychiatry. 2005 Dec 1;51(4):340-9.

[19] Judd F, Jackson H, Fraser C, Murray G, Robins G, Komiti A. Understanding suicide in Australian farmers. Soc Psychiatry Psychiatr Epidemiol. 2006 Jan;41(1):1-10.

[20] Alston M. Rural male suicide in Australia. Soc Sci Med. 2012 février;74(4):515-22.

[21] Bryant L, Garnham B. Beyond discourses of drought: The micro-politics of the wine industry and farmer distress. J Rural Stud. 2013;32:1-9.

[22] Bryant L, Garnham B. The fallen hero: masculinity, shame and farmer suicide in Australia. Gend Place Cult. 2015 Jan 2;22(1):6782.

[23] Yvan Droz, Miéville-Ott V, Jacques-Jouvenot D, Lafleur G. Malaise en agriculture. Une approche interdisciplinaire des politiques agricoles France-Québec-Suisse. Paris Karthala; 2014. 194 p.

[24] Jacques-Jouvenot D. Une hypothèse inattendue à propos du suicide des éleveurs : leur rapport aux savoirs professionnels. Etudes Rural. 2014 Jul 23;193(1):45-60.

[25] Deffontaines N. La souffrance sociale chez les agriculteurs. Etudes Rural. 2014 Jul 23;193(1):13-24.

[26] Célérier S. La belle vie désespérée des agriculteurs. Etudes Rural. 2014 Jul 23;193(1):25-44.

[27] Spoljar P. Problématique suicidaire en agriculture : une difficile évaluation. Perspect Interdiscip Sur Trav Santé [Internet]. 2014 Jan 17 [cited 2015 Nov 27];(16-3). Available from: http://pistes.revues.org/3650 
[28] Prévitali C. Les conditions du suicide des professionnels agricoles. Pensée Plurielle. 2015 Jun 12;n 38(1):105-21.

[29] Labbe E, Blanquet M, Gerbaud L, Poirier G, Sass C, Vendittelli F, et al. A new reliable index to measure individual deprivation: the EPICES score. Eur J Public Health. 2015 Aug 1;25(4):604-9.

[30] Ware J, Kosinski M, Keller SD. A 12-Item Short-Form Health Survey: construction of scales and preliminary tests of reliability and validity. Med Care. 1996 Mar;34(3):220-33.

[31] Abdi H, Williams LJ, Valentin D. Multiple factor analysis: principal component analysis for multitable and multiblock data sets. Wiley Interdiscip Rev Comput Stat. 2013 Mar;5(2):149-79.

[32] Janzen JM, Arkinstall W. The Quest for Therapy in Lower Zaire. University of California Press; 1978. 308 p.

[33] Augé M. L'Anthropologie de la maladie. L'Homme. 1986;26(97/98):81-90.

[34] Beck F, Guignard R, Richard JB, Wilquin J, Peretti-Watel P. Augmentation récente du tabagisme en France: principaux résultats du Baromètre santé, France, 2010. Bull Épidémiologique Hebd InVS. 2011;(20-21):230-3.

[35] OECD. Obesity and the Economics of Prevention. Available from: /content/book/9789264084865-en

[36] Belyea MJ, Lobao LM. Psychosocial Consequences of Agricultural Transformation: The Farm Crisis and Depression. Rural Sociol. 1990 Mar 1;55(1):58-75.

[37] Salmona M. Souffrances et résistances des paysans français: Violences des politiques publiques de modernisation économique et culturelle. Paris L'Harmattan; 1994. 254 p.

[38] Fuller JD, Kelly B, Law S, Pollard G, Fragar L. Service network analysis for agricultural mental health. BMC Health Serv Res. 2009 May 29;9:87.

[39] Isaac M, Elias B, Katz LY, Belik S-L, Deane FP, Enns MW, et al. Gatekeeper training as a preventative intervention for suicide: a systematic review. Can J Psychiatry Rev Can Psychiatr. 2009 Apr;54(4):260-8.

[40] Katerina Kavalidou SM. Farmers' contact with health care services prior to suicide: Evidence for the role of general practitioners as an intervention point. Aust J Prim Health. 2013. 